\title{
The Role of Media Resources in the Process of Self-Education
}

\author{
Muslimov N.A. ${ }^{1}$, Umarova Z.A. ${ }^{2}$ \\ ${ }^{1}$ Doctor of Pedagogy, Professor, Tashkent State Pedagogical University, Uzbekistan \\ ${ }^{2}$ Doctoral student of Tashkent state pedagogical university, Uzbekistan
}

\begin{abstract}
This article discusses media resources influence in self-education. Methods of formation of students' media-information competencies in the organization of self -education of students through media resources, ensuring their activity and independence in cognitive activity, the formation of professional skills, and the development of creative and critical thinking skills are covered. The technique proposed in media instruction models is more often than not based on cycles (pieces, modules) of imaginative and play errands that are effectively utilized by instructors in the course and out of course exercises.
\end{abstract}

Keywords: Media Education, Media Culture, Media Text, Media Resource, Self - Education

Received: December 27, 2020

Revised: January 3, 2021

Accepted: January 9, 2021

\section{Introduction}

It is no coincidence that the XXI century is called the century of modern digital technologies and information flow. We all know that in today's information age, information is interpreted as the most powerful weapon: "Do you have information? So you are armed." It is necessary not only to use the rapidly evolving flow of information correctly and efficiently, but also to create, store and process them.

Based on these requirements, one of the most pressing issues for all educational institutions is a new direction in pedagogy as a practical solution to increase the information literacy of students, the development of their media and digital competencies - the growing interest in the experience of media education.

\section{Literature Review}

The issue of media education has been studied by many foreign researchers, including A. Fedorov, Yu. Usova, I. Chelisheva, E. Bondarenko, L.Masterman, and others.

UNESCO considers media education as a priority area of pedagogical development in the XXI century and defines it as follows: "Media education is related to all types of media (print and graphics, audio, screen, etc.) and various technologies; it allows people to understand how to use mass communication in their communities, to acquire the skills to use the media in communication with other people; how to: (1) analysis, critical interpretation and creation of media texts; (2) identify the sources of media texts, their context, their political, social, commercial and cultural interests; (3) implementation of media texts and values of the distributed media; (4) create and distribute their own media texts and select appropriate media to attract an interested audience; (5) have access to the media for both perception and development".

Media pedagogue Fedorov (2001) said that media education is "the process of personal development and education through the use of mass media in order to form a culture of communication with the media, creative, communicative and critical thinking skills, interpretation, analysis and evaluation of media texts, various forms of self-expression using 
media technology." Benetoli et al. (2015) describes media education as "preparing students to live in an informed space by enhancing media-educational aspects in the study of various academic disciplines.

Sharikov \& Cherkashin (1991); Holmberg (2005); Jarvis et al (2003) described media education as teaching practical skills and theory to master modern media, which is considered a special and autonomous part of the field of knowledge in pedagogical theory and practice. Usov (2000) in his research studied media education as a system of use of mass media and communication (print, radio, film, television, video, computer technology, photography) in personal development of learners. The system of development itself, in contrast to the traditional disciplines that accumulate knowledge, primarily involves the process of emotional and intellectual development of the learner, the practice of artistic and creative activity that simulates his potential."

\section{Methods}

Today, the problem of introducing media education in universities is becoming increasingly important. Media education is recommended for inclusion in the national curricula of all countries, as well as in additional, informal and "lifelong" education systems.

Given that the curriculum of the higher education system of our country does not provide special lessons on teaching media education, today one of the most advanced, promising types of education in the integration of media education components is self - education.

Self - education is an integral part of the student education and training system, aimed at the free choice and mastering of additional education programs by students (Gibbons, 2003).

The self - education system develops students' interest in independent creative and scientific activities, implements important adaptation processes for the younger generation that allow them to demonstrate their abilities and live in a modern society, which plays an important role in training independent and mature personnel (Crowe et al., 2008; National Research Council, 2012; Grabinger \& Dunlap, 1995)

According to the methodology we propose, the organization of self - education of students on the basis of media resources is governed by the process of teaching and learning in the form of digital education on special programs organized according to the choice and needs of students.

\section{Result and Discussion}

The organization of independent educational processes on the basis of media resources in modern socio-cultural conditions provides educational and developmental opportunities for students (Shaidullina et al., 2017; Vaganova et al., 2018; Læss $\oslash$ (2010). They allow students to increase their knowledge both in academic subjects and in the field of media, contribute to the development of a culture of mastering the media space, and develop social activism. In addition, in the process of self-education organized on the basis of media resources, learners will have the opportunity to develop their individuality, independence of thinking, creative thinking, and media perception, ability to interpret and analyze media texts and gain new knowledge about media culture in general. Another important aspect of this methodology is that it is suitable for digital learning practice, i.e. the student has the opportunity to study online at any time, in any place, independently through any digital device (computer, tablet, smartphone) while performing educational project tasks based on media resources.

The method we propose combines the advantages of different methodologies, in particular, the integration of media resources into the educational process, such as the methods used in media education, independent learning in a specially organized learning environment, such as 
the Montessori method. At this point, if we briefly dwell on the mutually similar principles of the proposed methodology and the Montessori methodology, the main idea of these methodologies can be explained as follows: "Help me do it myself". That is, the learner has a free and independent choice of what to learn and what to do, and independent learning at an individual pace, based on their own experience: making mistakes and correcting them, with the educator handing over the learning materials to the learner and showing the correct way to work with them. It then allows the learner to study the material independently. The learner first works, learns as shown with the material, and then performs various exercises. Materials based media resources allow the student to learn, to see and correct their mistakes by one's own will and independently. In this case, teacher participates in this process to guide the student's independent activities "Helping them doing it themselves". Umarova (2020) stated If a student makes a mistake, the teacher tries not to interfere, allowing the learner to find the mistake and correct it himself. If the learner asks for help, the teacher immediately does so, i.e. clarifies and explains the mistakes.

The experience of foreign practice shows that project activities are increasingly used in the organization of media education in universities. The methodology we propose also uses educational case-projects consisting of media resources. They serve as an important tool for developing cognitive activity, creativity, and at the same time shaping students 'personal qualities and professional skills.

The media case-project method, which focuses on students' independent research activities, focuses on applying the acquired knowledge in practice and acquiring new knowledge about media culture. The organization of project activities on the basis of media materials allows students to become active participants in the learning process, as well as makes a huge contribution to the development of creative, critical thinking skills. Project work is especially important in the process of developing students' critical thinking skills. Because in the process of independent learning, the creative work in a media case-project helps to form 'constructive critical thinking' that is difficult to teach in a conventional 'lesson' system. In this case, "this is right, this is wrong" assessment scheme does not work and students develop their own analytical views on the data.

The effectiveness of project methodologies in media education depends on the following reasons: (a) Project methods are person-centered, the developmental aspect of education is one of the leaders in media education; (b) Learning in the process of project implementation is self-motivating, which means increased involvement and interest in the work being done; (c) Finally, the hierarchy of "teacher-student" relationships in project methodologies differs significantly from traditional teaching methods.

In the experience of foreign countries we can observe the following types of project activities: work with students on creative media-educational projects in the field of "Media Education" of pedagogical universities, for example, the creation and creative integration of their own media products (films, newspapers, socio-pedagogical advertising, etc.) developing school event scenarios for students of different ages, and so on. It is well known that such tasks, which can be performed in practice, are of particular interest to learners. The methodology proposed in media education models is usually based on cycles (blocks, modules) of creative and play tasks that are successfully used by teachers in class and out of class activities.

Creative tasks based on media materials perform the functions of teaching, adapting, developing and managing: (1) The learning function is aimed at acquiring knowledge of theories and laws, methods of perception and analysis of media texts; (2) Adaptive function implies the ability to apply knowledge in other situations; (3) Developing function - aimed at 
developing the motivational, volitional and other features and qualities of a person, the experience of creative communication with the media; (4) Management function - involves creating the best conditions for the whole process of media education.

\section{Conclusion}

The basic methodological principles and methods of media education are aimed at developing creative and intellectual potential, broadening worldviews, cognitive processes and selfawareness. Through the organization of self- education of students' via media resources, it will be possible to increase the effectiveness of teaching and learning practice, to bring it to a new level of quality.

\section{References}

Benetoli, A., Chen, T. F., \& Aslani, P. (2015). The use of social media in pharmacy practice and education. Research in social and administrative pharmacy, 11(1), 1-46.

Crowe, A., Dirks, C., \& Wenderoth, M. P. (2008). Biology in bloom: implementing Bloom's taxonomy to enhance student learning in biology. $C B E$-Life Sciences Education, 7(4), 368-381.

Fedorov, A. (2003). Media education and media literacy: experts' opinions. Available at SSRN 2626372.

Fedorov, A. V. (2001). Mediaobrazovaniye: Istoriya, teoriya i metodika [= Media Education: History, Theory and Methods], Rostov, 708 p.

Gibbons, M. (2003). The self-directed learning handbook: Challenging adolescent students to excel. John Wiley \& Sons.

Grabinger, R. S., \& Dunlap, J. C. (1995). Rich environments for active learning: A definition. ALT-J, 3(2), 5-34.

Holmberg, B. (2005). Theory and practice of distance education. Routledge.

Jarvis, P., Holford, J., \& Griffin, C. (2003). The theory \& practice of learning. Psychology Press.

Læss $\oslash$ e, J. (2010). Education for sustainable development, participation and socio-cultural change. Environmental Education Research, 16(1), 39-57.

National Research Council. (2012). Education for life and work: Developing transferable knowledge and skills in the 21st century. National Academies Press.

Shaidullina, R. M., Amirov, A. F., Muhametshin, V. S., \& Tyncherov, K. T. (2017). Designing Economic Socialization System in the Educational Process of Technological University. European journal of contemporary education, 6(1), 149158.

Sharikov, A. V., \& Cherkashin, E. A. (1991). Experimental Programs of Media Education. Moscow: Academy of Pedagogical Sciences, Research Institute of Educational Means.

Umarova, Z. (2020). Modern and Innovative Approaches to the Organization of Students' Self-Education in Higher Educational Institutions. Journal La Edusci, 1(4), 5-8.

Usov, Y. (2000). Screen Arts as a New Way of Thinking. Art and Education, (3), 48-69.

Vaganova, O. I., Zanfir, L. N., Smirnova, Z. V., Chelnokova, E. A., Kaznacheeva, S. N., \& Maseleno, A. (2018). On the linguistic training of future teachers of unlike 
specialties under the conditions of Russian professional education. International Journal of Engineering and Technology (UAE), 7(4), 4090-4095. 